\title{
Online, Blended And Technology-Enhanced Learning: Tools To Facilitate Community College Student Success In The Digitally-Driven Workplace
}

Dawn Levy, Kingsborough Community College, The City University of New York, USA

\begin{abstract}
Community colleges have embraced distance education as a means to provide increased flexibility and access to their large numbers of non-traditional students. Retention rates and student achievement measures alone may not reflect all of the benefits and opportunities that online learning, blended or hybrid learning, and technologyenhanced learning may afford these students. Online learning resources should be viewed as a tremendous valueadded benefit for community college students, not only for the content conveyed, but also for fostering the digital readiness, cultivating the professional personas, and encouraging the self-directed learning needed to succeed in the digitally-driven workplace.
\end{abstract}

Keywords: Community College; Online Learning; Blended Learning; Technology-Enhanced Learning

\section{INTRODUCTION}

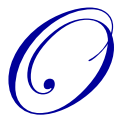

nline learning continues to proliferate across all disciplines and on all college campuses at both private and public four-year and two-year institutions (see Allen \& Seaman, 2016; Graham, Woodfield \& Harrison, 2013; Xu and Jaggars, 2013). In 2016, Allen and Seaman's thirteenth annual comprehensive study tracking online education in the United States found that $28 \%$ of all higher education students took at least one course at a distance, and more than two-thirds of those students $(67 \%)$ did so at a public institution (Allen \& Seaman, 2016).

In particular, community colleges have incorporated online education to meet the needs of their large numbers of non-traditional students (Jaggars, Edgecombe, \& Stacey, 2013). Many community college students frequently balance numerous and significant obligations in addition to school (Barker, 2015) and are often either older, work full or part-time, raise families, live a long distance from campus, or face huge personal challenges (Barker, 2015; Deschacht \& Goeman, 2015; Jaggars, 2014).

Universities are increasingly concerned with customer satisfaction and loyalty (Kilburn, Kilburn \& Davis, 2016; Neumann, Neumann \& Lewis, 2017). They have embraced online learning modalities to provide increased flexibility and access for their students (see Crawford, Barker \& Seyam, 2014; Deschacht \& Goeman, 2015; Kilburn, Kilburn, Davis, 2016; Palmer, Shaker \& Hoffman, 2014; Wach, Broughton \& Powers, 2011; Xu \& Jaggars, 2013). For example, the City of New York (CUNY), the nation's largest urban university, announced a hybrid initiative in late 2009 to increase the number of blended courses throughout the university (Wach, et al., 2011). Similarly, many of CUNY's current academic-technology initiatives focus on reducing barriers of time and distance for working students and for those who have obligations that make it challenging to attend classes on campus. ("Online Instruction at CUNY," 2017). Most recently, CUNY's Open Educational Resources (OER) initiative aims to curate course materials that are freely available online and can be updated in real time ("Academic Technology Initiatives," 2017). 
Online learning has the potential to challenge students because it offers many additional tools to facilitate communication, collaboration and the exchange of information (Meyers, 2008). Teaching and learning with technology generally takes one of three forms. The term online is usually reserved for classes that utilize an online platform only without any traditional face-to-face delivery, hybrid/blended models mix face-to-face and online components to varying degrees, and web/technology enhanced courses use web-based technology to enhance a traditional face-to-face course (Allen \& Seaman, 2016). The majority of citations to online learning in this paper refer to using technology and digital resources in any of these three formats.

\section{ACADEMIC SUCCESS AND THE ONLINE LEARNING ENVIRONMENT}

Studies have tracked the impact of online and hybrid courses on student achievement and retention as colleges and universities expand their online offerings (see, for example, Crawford, et al. 2014; Palmer, Shaker \& HoffmanLongtin, 2014; Kaufman, Greenhouse, She \& Shi, 2016; Shea, \& Bidjerano, 2014; Xu \& Jaggars, 2011; Xu \& Jaggars, 2013). Retention rates and overall academic success rates tend to be lower for students in fully-online courses (Xu \& Jaggars, 2013). For example, in a large-scale comprehensive study of the Washington State community and technical college system, taking a particular course fully-online decreased the likelihood of persistence, as measured by retention rates, by seven percentage points and lowered the student's grade by about .3 points (Xu \& Jaggars, 2013). A similar widespread study of the introductory math and English courses in the Virginia community college system found that students in fully-online classes fared worse in persistence and end-ofcourse grades (Xu \& Jaggars, 2011).

Other studies suggest that community college students do as well in hybrid classes as they do in traditional courses (Crawford et al. 2014; Palmer, et al., 2014; Ryan et al. 2016; Xu \& Jaggars, 2013). Hybrid or blended courses may offer just the right mix of independent online learning while still providing the personal support and motivation associated with a face-to-face instruction. Also, research shows that students in hybrid classes may feel a stronger sense of community than those in a traditional setting (Youngju, Jaeho, \& Taehyun, 2013). Other studies have found that although blended learning may have a negative impact on course retention, it does impact positively on student performance (Deschacht \& Goeman, 2015). Most studies in the community college setting focus on student perseverance as measured by retention rates and student achievement based upon grades (Xu \& Jaggars, 2011; Xu \& Jaggars, 2013). However, these measures are only two assessment criteria for determining the success of hybrid and fully-online models. They alone may not reflect the other benefits and opportunities that online learning may provide to these students.

For example, community college students who took at least some online courses are still more likely to earn a degree than their non-digital counterparts (Shea \& Bidjerano, 2014). Moreover, the simple availability of onlinedegree-earning opportunities increases the access to higher education that might otherwise be unattainable for many prospective students (Deschacht \& Goeman, 2015). Additionally, frequent and effective digital interactions between instructors and students may encourage student commitment to the course and result in a stronger academic performance (Jaggars \& Xu, 2016; Xu \& Jaggars, 2013). Research also suggests that hybrid courses with a high level of teaching presence, coupled with student support services, orientations and assessments for online readiness, can facilitate the best possible outcome for students (Crawford \& Persaud, 2013; Graham et al. 2013).

\section{THE ONLINE LEARNING ENVIRONMENT CULTIVATES ATTRIBUTES FOR CAREER SUCCESS}

The process of using online learning resources, independent of the content conveyed, is a tremendous value-added benefit for community college students. As employers continue to stress the importance of non-cognitive soft skills including effective communication, teamwork, leadership, and self-motivation as integral to success at work (Gray, 2017), technology-enhanced courses help students operate, communicate, collaborate and network on a digital platform in preparation for their future jobs and careers. Participation in technology-enriched courses fosters digital readiness, cultivates professional personas, and encourages self-directed knowledge acquisition. Moreover, attention to detail in writing, time-management, and follow-through, cited as among the top skills essential for the modern workforce (Beaton, 2017), are integral components of the online learning experience. 


\section{Digital Readiness}

A modern challenge in higher education is how to prepare students for their future jobs and careers through a digital lens. While discipline based knowledge will always remain critical, there is an increasing emphasis on the ability to develop, sustain and practice that knowledge through a general technology-driven paradigm. It is difficult to think of any vocation or profession that has not reimagined or redefined itself to include digital preparedness as a valuable skill. Hence, a goal of online learning is to empower community college students with a general digital readiness encompassing essential skills that cross disciplines and professions. Particularly, with the shorter two-year community college time frame, efficiency is key. Classes that integrate technology into the course content aim to truly immerse students in simulated real world interactions.

\section{Digital Literacy and Digital Citizenship}

Digital readiness encompasses two major components, digital literacy and digital citizenship. Digital literacy entails using technology strategically to find and evaluate information, produce original digital content, and share information with others (Heitin, 2017). Digital citizenship generally refers to the norms of appropriate and responsible technology use (www.digitalcitizenship.org).

To enhance students' digital literacy, online educational opportunities help students develop skills of computermediated communication, web-based research, and online collaboration ("Online Instruction at CUNY," 2017). Learning management systems and digital educational materials require students to navigate an unfamiliar platform, share their work, and communicate with peers and instructors in the ways they will be expected to communicate and engage post-college. Students must learn how to effectively parse through the wealth of information available online to find relevant and reliable information. Discussion boards, blogs and online collaboration tools also help develop students' online communication literacies.

Digital citizenship in higher education includes adherence to the legal and ethical codes of conduct set out in school academic integrity policies that outline acceptable technology use and practice. Requiring students to abide by acceptable online use policies sensitizes them to appropriate professional technology use. Students have many opportunities to practice their digital citizenship, for example, when emailing professors, responding to discussion board posts, and communicating with colleagues in an online collaborative work session. Digital citizenship also refers to the skills and access needed for participation in the information age (Mossberger, Tolbert, \& McNeal, 2008). Developing these skills is critical for community college students because evidence shows that an increase in access and frequency of internet use leads to increased income, increased civic engagement and increased political participation (Mossberger et al.).

\section{Benefits of Digital Readiness}

A broad percentage of community college students do not have internet access at home (Jaggars, 2014b) and this may contribute to the digital divide, the social, educational and economic inequalities between those who have digital access and those who do not (Mossberger et al., 2008). Online learning may help bridge the digital divide by affording these students access to campus digital resources and the opportunity for a degree that might have otherwise alluded them because of work and family obligations. Moreover, their enrollment in a hybrid or blended course ensures that they will be on campus at least some of the time to utilize the digital resources available to them.

The more experience students have using computers and related technology for educational and professional use, the more they improve their confidence to complete workplace related tasks in the future. Self-efficacy, the belief in one's capability to organize and execute courses of action to achieve goals (Bandura, 1997), will influence an individual's commitment to achieving their desired outcome (Alquarashi, 2016). Assignments in fully-online, hybrid and technology-enhanced courses promote digital self-efficacy so that students are prepared for digital tasks that they will encounter in their jobs and professional careers. 


\section{Professional Persona}

Developing one's professional online persona takes practice. Online learning assignments may help students transition from their familiar modes of communication on social media and related platforms to adoption of a more comprehensive professional online persona. Instructors of technology-enhanced courses serve as models for appropriate online etiquette and reinforce that online professional interactions, for example, through email, video conferencing, tutorials and webinars, are different than communicating on social media. Technology-enhanced learning helps cultivate professional online personas in several ways.

\section{Appreciation for the Niceties and Nuances of Professional Written Communication}

In the absence of formal online learning modalities, students are apt to interact online with instructors, classmates, co-workers, and supervisors in an informal way. Work and related online interactions should not mimic social conversations. Tone, voice, demeanor, grammar, punctuation and word usage should be appropriately different. Work-related emails, while not necessarily formal academic writings, should follow appropriate conventions. Online learning modalities allow students to shift the focus from friend to colleague in their discussions and responses to opinions and suggestions. Instructors in the online learning environment model professional communication in their announcements, greetings, discussion boards and grading responses to reflect this nuanced style and help condition students to internalize these characteristics.

\section{Opportunity to Develop Interactions with Colleagues in an Online Arena}

Online resources, including discussion boards and online collaborative group work, simulate how people in our techdriven world work together with colleagues, supervisors, clients and others in the absence of face-to-face contact. Today, conference room meetings are often the exception rather than the norm. Online platforms that facilitate student team projects, while more complicated to integrate and monitor, are seen as valuable simulations of modern day collaboration tools.

\section{Student Empowerment}

Language barriers, cultural inhibitions, and prior history of poor academic performance may inhibit community college students from participating in face-to-face class discussions. The online learning environment may increase the frequency and quality of student participation because students may be emboldened to speak up and express their opinions in the absence of in-person instructors and peers. Instructors who require mandatory responses show that they value their students' opinions. Also, incredibly reticent students who might never venture to offer their opinion in class may often express incredible insights online. A positive and reassuring response by an instructor to such an online post is very likely to encourage that same shy student to then speak up in class. Finally, since student participation in online work is often asynchronous, students may complete coursework at their own pace and have the opportunity to develop more thoughtful responses and cogent arguments.

\section{Self-Directed Learning}

The ability to be intrinsically motivated, self-driven and persistent are advantageous student characteristics that make a person more likely to succeed academically and beyond (Linnenbrink \& Pintrich, 2002). Independent learners are capable of acquiring knowledge anytime, in any place, through any means, at any age because they take the initiative and the responsibility for what occurs as they select, manage, and assess their learning activities (www.self-directedlearning.com). Students who persist in online courses have higher levels of academic locus of control and metacognitive self-regulation skills (Deschacht \& Goeman, 2015). Online learning promotes selfdirected learning in several ways.

\section{Increased Opportunities for Independent Learning}

When students tackle material on their own before coming to class, they are constructing personal knowledge (Strayer, 2012). This life skill becomes increasingly important for career success. Employees are expected to access 
online tutorials and webinars to independently master work-related content and tasks. Students in online learning courses are prepared for this type of independent learning because schools schedule a portion of the teaching and learning on a student's time outside of the classroom. Instructors build these independent learning opportunities into the curriculum and mandate participation as part of a student's grade. Flipped instruction, video quizzing, and podcast lectures with follow-up exercises are some of the tools used to condition students to learn independently.

\section{Built-In Time Management Practice}

To succeed in a hybrid class, students must develop or enhance their time-management skills that are critical to academic and professional success. Understanding the need for managing one's time and completing tasks without the routine of regular classroom attendance are two student dispositions associated with success in reduced-contact classes (Wach et al., 2011). Instructors cannot presume these skills in all community college students (Wach et al., 2011), but some intrinsic aspects of the online paradigm help students develop these skills through practice at selfpacing to meet upcoming deadlines. When instructors increase the frequency of assignments, routinely monitor time stamps on online submissions, and make assignments unavailable immediately after the due date, students become more mindful of time and the consequences of non-compliance. Since students have the ability to submit online work anywhere and at any time, they are held more accountable for coursework.

\section{An Active Learning Paradigm}

Traditional delivery often creates passive students who wait for information to be conveyed to them. The teacher is in control of the path, pace, and intensity of the learning. In contrast, the online learning environment prompts students to take a more active, independent role by allowing them to set the time, place and schedule of their learning. Students must initiate the learning process by logging in and engaging. Given the increased flexibility and control that they feel the online platform affords them, community college students may be more vested in their personal success.

\section{Quick and Enhanced Feedback Provides Motivation}

The type of instructor feedback that is available on learning management systems can motivate students to engage more thoroughly and learn more in depth. With auto grading and personalized feedback features, students can track their own individual progress and begin to connect their specific learning patterns to their achievement rates. This encourages students to develop metacognitive abilities to analyze their own learning styles and habits.

\section{SUPPORT FOR SUCCESSFUL ONLINE LEARNING}

As online learning continues to integrate into the foundation of higher education, a strong online teacher presence and a commitment to student support must be priorities in online teaching pedagogy. Jaggars (2014) suggests that the key to success in fully-online courses is for instructors to incorporate strong interpersonal connections and instructor guidance, particularly for community college students who often lack confidence in their academic abilities. Video-or audio-taped narrations that allow students to view or hear the instructor walk them through specific activities have been shown to personalize and forge personal connections with the instructor (Jaggars 2014; Xu \& Jaggars, 2013). Instructors of blended or hybrid courses who reinforce the online portion during the face-toface instruction by consistently referring and responding to the online assignments ensure stronger student buy-in and compliance for the online portion.

Moreover, instructors who put in the effort to design and present a well-organized site establish the reliability and integrity of their courses from the outset. Structuring and preparing effective online learning materials requires a large investment of time. Students are encouraged to engage with the online materials when they feel that their instructors invest effort into organizing the online content and making the site user-friendly. Also, when online instructors use technology tools to demonstrate that they care about their students, they provide them with the encouragement and motivation needed to support their academic success (Jaggars, 2014). For example, when instructors post friendly greetings, reminders, and materials of interest to students, they are encouraging them to participate in a dynamic online learning community. Likewise, when instructors schedule asynchronous online 
assignments, they demonstrate their respect for the demanding work and life schedules of many community college students.

In addition, if students know how to navigate the learning management system and are familiar with where to look for particular resources, participation and submission of online assignments is likely to increase tremendously. Sufficient college-wide support services like technical support, library services, tutoring and student orientation programs on how to access support services, further support the online platform (Crawford \& Persaud, 2013) and are likely to increase retention and success (Graham et al. 2013).

\section{CONCLUSION}

It is true that online learning demands that students take a more active role and bear a larger share of the responsibility for their learning (Lei, 2010; Schmidt \& Ralph, 2016) and that for many community college students this can pose a serious barrier to success. However, it is not enough to offer online learning opportunities to community college students merely to provide them with flexibility or access. It is equally important for all forms of online learning to help develop their skills for independent learning and career preparedness. If utilized properly, technology can help community college students succeed academically and prepare them for future career success. Therefore, instructors must be cognizant to continually relate the benefits of working online to a student's professional aspirations.

As community college students enter the digitally-driven workplace, the skills and expertise gained from learning discipline specific content through the online environment will inform their professional competencies and drive their performances at work. Rather than questioning whether online learning belongs in community colleges, these institutions must continue to focus their efforts on increasing access, enhancing online pedagogies, maintaining strong teacher presence, and expanding student and faculty support systems to foster student success in the online learning environment.

\section{AUTHOR BIOGRAPHY}

Dawn Levy, JD, is an Assistant Professor in the Department of Business at Kingsborough Community College, The City University of New York (CUNY), where she teaches Business Law and related business courses in both traditional and hybrid formats. She is an Advisory Board member at the Kingsborough Center for e-Learning $(\mathrm{KCeL})$ and serves on the college's Advisory Committee for Online Learning and Programming. Prior to teaching at CUNY, Professor Levy was a corporate associate at the law firm of Sullivan \& Cromwell in New York practicing corporate, securities and real estate law.

\section{REFERENCES}

“Academic Technology Initiatives: Open Educational Resources”. (2017, July 11). Retrieved 2017, July 11 from http://www2.cuny.edu/academics/current-initiatives/academic-technology/academic-technology-initiatives/

Allen, I., \& Seaman, J. (2016) Online Report Card: Tracking Online Education in the United States. 2016. Babson Survey Research Group and Quahog Research Group, LLC. https://onlinelearningconsortium.org/read/online-report-cardtracking-online-education-united-states-2015/.

Alqurashi, E. (2016). Self-efficacy in online learning environments: A Literature Review. Contemporary Issues in Education Research, $9(1), 45$

Badura, A. (1997). Self-efficacy: The exercise of control. New York: W.H. Freeman.

Barker, Joel. (2015). Benefits of hybrid classes in community colleges. Contemporary Issues in Education Research, 8(3), 143146.

Beaton, C. (2017, January 6). Top employers say millennials need these 4 skills in 2017. Retrieved from https://www.forbes.com/sites/carolinebeaton/2017/01/06/top-employers-say-millennials-need-these-4-skills-in2017/\#6b3e104f7fe4

Crawford, C., Barker, J., \& Seyam, A. (2014). The promising role of hybrid learning in community colleges: Looking towards the future. Contemporary Issues in Education Research, 7(3), 237-242.

Crawford, C., \& Persaud, C. (2013) Community colleges online. Journal of College Teaching \& Learning, 10(1), 75-82. doi:http://dx.doi.org/10.19030/tlc.v10i1.7534 
Deschacht, N., \& Goeman, K. (2015). The effect of blended learning on course persistence and performance of adult learners: A difference-in-differences analysis. Computers \& Education, 87, 83-89. doi:10.1016/j.compedu.2015.03.020

Graham, Charles R., Woodfield, Wendy, \& Harrison, J. Buckley. (2013). A framework for institutional adoption and implementation of blended learning in higher education. The Internet and Higher Education, 18, 4.

Gray, Alex (2017, February 16). Goodbye, Maths and English. Hello, teamwork and communication? Retrieved from https://www.weforum.org/agenda/2017/02/employers-are-going-soft-the-skills-companies-are-looking-for/

Heitin, L. (2017). What is digital literacy? Education Week, 36(12), 5-6. Retrieved from http://www.edweek.org/ew/articles/2016/11/09/what-is-digital-literacy.html

Jaggars, S. S. (2014). Democratization of education for whom? Online learning and educational equity. Diversity and Democracy, 17(1). Retrieved from https:/www.aacu.org/diversitydemocracy/2014/winter/jaggars

Jaggars, S.S., Edgecombe, N. and Stacey, G.W. (2013). Research overview: Online course outcomes. New York, NY: Columbia University, Teachers College, Community College Research Center. https://ccrc.tc.columbia.edu/media/k2/attachments/online-learning-practitioner-packet.pdf

Jaggars, S. S., \& Xu, D. (2016). How do online course design features influence student performance? Computers \& Education, 95, 270-284. doi:10.1016/j.compedu.2016.01.014

Kilburn, Brandon, Kilburn, Ashley, \& Davis, Dexter. (2016). Building collegiate e-loyalty: The role of perceived value in the quality-loyalty linkage in online higher education. Contemporary Issues in Education Research, 9(3), 95-102.

"Led by California, Educators Strive To Close Online Learning Gaps". (2015). Community College Week, 27(21), 6-7.

Lei, S. A., \& Gupta, R. K. (2010). College distance education courses: Evaluating benefits and costs from institutional, faculty and students' perspectives. Education, 130(4), 616-631.

Linnenbrink, E. A., \& Pintrich, P. R. (2002). Motivation as an enabler for academic success. School Psychology Review, 31(3), 313.

Meyers, S. A. (2008). Using transformative pedagogy when teaching online. College Teaching, 56(4), $219-224$.

Mossberger, K., Tolbert, C. J., \& McNeal, R. S. (2008). Digital citizenship: The internet, society, and participation. Cambridge, Mass: MIT Press.

Neumann, Y., Neumann, E., \& Lewis, S. (2017). The assessment of online degree programs: Lessons from recent alumni. Contemporary Issues in Education Research, 10(1), 67-76. http://dx.doi.org/10.19030/cier.v10i1.9894

"Online Instruction at CUNY". (2017, July 11). Retrieved 2017, July 11 from http://www2.cuny.edu/academics/currentinitiatives/academic-technology/

Palmer, M. M., Shaker, G., \& Hoffmann-Longtin, K. (2014). Despite faculty skepticism: Lessons from a graduate-level seminar in a hybrid course environment. College Teaching, 62(3), 100-106. doi:10.1080/87567555.2014.912608

Ryan, S., Kaufman, J., Greenhouse, J., She, R., \& Shi, J. (2016). The effectiveness of blended online learning courses at the community college level. Community College Journal of Research \& Practice, 40(4), 285-298. doi:10.1080/10668926.2015.1044584

Schmidt, Stacy M. P., \& Ralph, David L. (2016). The flipped classroom: A twist on teaching. Contemporary Issues in Education Research, 9(1), 1-6.

Shea, P., \& Bidjerano, T. (2014). Does online learning impede degree completion? A national study of community college students. Computers \& Education, 75, 103-111. doi:10.1016/j.compedu.2014.02.009

Strayer, J. (2012). How learning in an inverted classroom influences cooperation, innovation, and task orientation. Learning Environments Research, 15, 171-193.

Xu, D., \& Jaggars, S. S. (2011). The effectiveness of distance education across Virginia's community colleges: Evidence from introductory college-level math and English courses. Educational Evaluation and Policy Analysis, 33(3), 360-377.

Xu, D., \& Jaggars, S. S. (2013). The impact of online learning on students' course outcomes: Evidence from a large community and technical college system. Economics of Education Review, 37, 46-57. doi:10.1016/j.econedurev.2013.08.001

Wach, Howard, Broughton, Laura, \& Powers, Stephen. (2011). Blending in the Bronx: The dimensions of hybrid course development at Bronx Community College. Journal of Asynchronous Learning Networks, 15(1), 87-94.

Youngju, L., Jaeho, C., \& Taehyun, K. (2013). Discriminating factors between completers of and dropouts from online learning courses. British Journal of Educational Technology, 44(2), 328-337. doi:10.1111/j.1467-8535.2012.01306.x 
NOTES 